\title{
Epiphany
}

Epiphany: Vol. 4, No. 1, 2011

ISSN 1840-3719

\section{International Political Actors and State-Building Process in Bosnia-Herzegovina}

\author{
Ahmed Kulanić*
}

\begin{abstract}
This article analyzes the post-war period in Bosnia-Herzegovina and the role which international actors, mainly represented through the Office of High Representative (OHR), and local political actors played. The primary aim and significance of this article is to present to what extent OHR and local political actors contributed to the establishment of rule of law, security, stability, self-sustainability and creation of modern-functioning state. Therefore, the research questions of this paper address the role of international and local actors in state-building process and their contributions in the creation of a democratic state of Bosnia-Herzegovina. Furthermore, this article examines the roots, causes and results of the political crisis in Bosnia-Herzegovina. The international community, on one hand, never brought their objectives to the state of completion and full implementation, on the other hand, due to the excessive involvement of international community local political actors never held themselves accountable for current political predicaments. Therefore, both, the international community and local political actors must find a way and means to transform DPA Bosnia and Herzegovina towards possible EU member state Bosnia and Herzegovina by using bottom-up step by step state-building strategy.
\end{abstract}

Key words: Office of High Representative (OHR), local and international political actors, state-building, exit strategy, EU, NATO.

\footnotetext{
* Corresponding author: Ahmed Kulanić, Faculty of Arts and Social Sciences, International University of Sarajevo, Sarajevo, Bosnia and Herzegovina; e-mail: akulanic@ius.edu.ba; ahmedkula@yahoo.com
} 


\section{Introduction}

Since October 2011 general elections Bosnia-Herzegovina has been encountering with serious political crisis. More than one year after the elections, state-level government has not been formed and the question of legality and legitimacy of entity government in the Federation of Bosnia-Herzegovina, challenged by the Croat political parties especially by HDZBiH and HDZ1990, has continued. Current political predicaments, coupled with indifference and unwillingness of the international community to act and to seek solutions, are obvious indicators of current political crisis.

Political scene is furthermore complicated due to the special position and an involvement of the international community and the High Representative into the political affairs of Bosnia-Herzegovina. Different perceptions about such involvement among local political actors have been apparent since signing of the Dayton Peace Agreement (DPA). However, international involvement reached its climax due to political differences regarding the April Package, the High Representative's "Full Capacity," and last general elections in October 2010. The April Package represented first significant initiative for constitutional changes since signing of DPA made by local political actors under significant involvement of the international community.

It is significant to indicate that since 2006 many reforms have been initiated but most of them ultimately failed, which had significant impact on Bosnia-Herzegovina's path towards the EU. The international political actors began the transition of OHR in 2002 by appointment of the first European Union Special Representative (EUSR), and the transition continued as a result of the adoption of "five plus two platform" significant momentum occurred for the closure of OHR in 2008 (Abaspahić \& Bajrović, 2010, p. 2). Therefore, the past three years both international and local political actors have been focusing on the closure of the OHR. An emphasis on this issue became the most important and, as a result, affected all the other reforms and political processes.

Current political predicaments in Bosnia-Herzegovina put the international political actors in difficult position. The sixteenth year of 
the international community presence and its' High Representative resulted in very dependent and passive role of the local political actors in Bosnia-Herzegovina. Therefore, it is inevitable to ask to what extent and how international community and local political actors could respond effectively to the challenges of joining the EU and NATO, and how the socio-economic conditions of citizens in Bosnia-Herzegovina could be improved?

\section{The International Community and State-Building Process in Bosnia- Herzegovina}

The international community diverted from its focus from BosniaHerzegovinian as result of a relative peace, satisfying level of security, relative guaranties from returning to the conflict and the emergence of new conflicts worldwide. The major success of DPA, as many authors argued, was stopping the bloodiest war on European soil since World War II (Holbrooke, 1998; Chollet, 2005). Richard Holbrooke (1998) argued that the DPA did not aim to create a stable, functional and selfsustainable state but, simply, To End a War, as the title of his book clearly indicated (Farkas, 2003, p. 96). Similarly Carl Bildt (1998), first High Representative in Bosnia-Herzegovina, argued that Dayton was "the most ambitious document of its kind... aimed at the setting up a state on the basis of little more than ruins and rivalries of bitter war" (p. 352). DPA reaffirmed the continuity of the Republic of Bosnia-Herzegovina within internationally recognized borders. Internal organization is based on the entity model with two regions: entity Federation of BosniaHerzegovina and entity Serb Republic. However, the entity model as a unique state-organization after the conflict, affirmed ethnically based division of the unified country. Such a model hardly affirmed the sovereignty of Bosnia-Herzegovina and gave excessive powers to two entities, which at times act as 'sovereign states' (Ibrahimagić, 1999; Trnka, 2000, p. 319; Šarčević, 2009, p. 12).

The first phase after signing DPA represents mostly the period of consolidation of the international community in Bosnia-Herzegovina and an establishment of peace and security. During the first phase also led to the formation of Peace Implementation Council (PIC) and organization of 
international conferences, which were aimed at the implementation of DPA. The Bonn Conference, held in 1997, was marked as the most important because powers and jurisdictions of the High Representative increased, which contributed to the removal and ban of politicians who violated the provisions of the DPA (Peace Implementation Council (PIC), 1997a). Another significant peace conference was the Sintra Meeting which additionally gave a mandate to the High Representative to interpret "letter" and "spirit" of the DPA (PIC, 1997b).

The main objective of the international community during this phase was strengthening the role and position of the OHR in BosniaHerzegovina. Furthermore, in the period from 1995 to 2000, OHR led to the establishment of vital laws such as: The Law on Citizenship of Bosnia and Herzegovina (16 December, 1997); The Law on the Flag of Bosnia and Herzegovina (3 February, 1998); The Law on the National Anthem of Bosnia and Herzegovina (25 June, 1999); The Law on State Border Service (13 January, 2000) and The Law on the Human Rights Ombudsman of Bosnia and Herzegovina (14 December, 2000) (Belloni, 2001, p. 172). These laws contributed significantly towards the statebuilding of Bosnia-Herzegovina (de Guevara, 2009, p. 16). The international community also managed to establish several vital institutions such as: Indirect Taxation Authority (ITA), the State Border Service (SBS), the State Investigation and Protection Agency (SIPA), the Armed Forces of Bosnia and Herzegovina (AFBiH), the High Judicial and Prosecutorial Council (HJPC) and the Civil Service Agency (CSA).

Newly emerging crisis in Kosovo in 1999 turned the focus of the international community away from Bosnia-Herzegovina. Then, the attacks on the World Trade Center on the $11^{\text {th }}$ of September 2001 and the invasions of Afghanistan (2001) and Iraq (2002) have been marked as the most important crisis areas in the world (Hromić, 2006, p. 23). Such worldwide conflicts diverted an attention and focus of the international community from Bosnia-Herzegovina. The most obvious illustration of such shift is eminent in the reduction and decrement of the budget of OHR from 35 million Euros in 1999 to 25 million Euros in 2001 (OHR, 1998; PIC, 2001). Brussels' conference in May 2000 was a turning point in the transition process of the OHR and a milestone of the role of the 
international community in Bosnia-Herzegovina. From this period onwards the DPA implementation became subordinated to the Road Map of European Union (PIC, 2000a).

The PIC Brussels' meeting in 2000 gave more significant power to the European Union to monitor the implementation of DPA (Ramel, 2008, p. 11). Furthermore, the Road Map to the EU Stabilization and Association in March 2000 strengthened the European Union involvement and role (Hadžikadunić, 2005). Such developments have been perceived as the transition from PIC to the EU implementation of DPA. In addition, EU's requirements for the Candidate status and membership have been associated with the implementation of the DPA. The EU paved the way towards the „Road Map” by excessively using powers of the High Representative (Turčalo, 2008, p. 22). However, certain international and local political actors have been lobbying for restructuring the OHR because, as Gerald Knaus explained, "the imposition of constitutional changes by an order is a Draconian measure" (as cited in Tuathail, 2005, p. 63) would transform BosniaHerzegovina to a full protectorate, which is not the ultimate aim of the EU (Tuathail, 2005, p. 63). Consequently, Brussels Meeting in September 2001 specified OHR's role on institution building, economic reform, refugee return and the rule of law. Though ambitiously, the year 2005 was set for the implementation of these conditions and the withdrawal of the international community from Bosnia-Herzegovina (OHR, 2001).

Preoccupation of the international community with global hotspots primarily in Iraq and Afghanistan, as well as the EU taking over the leadership position in Bosnia-Herzegovina, eventually led to a decline in coherent politics of the international community and a delay in the establishment of the effective, stable and self-sustainable state of BosniaHerzegovina. Another factor that contributed towards questionable credibility and authority of the international community in BosniaHerzegovina was the introduction of so-called "five plus two" platform for closure of the OHR. Ultimately such platform targeted an achievement of a functional state and the closure of OHR. However, as outcomes indicate such platform was adopted without proper analysis of 
how to establish, in effect, an effective, functional, stable and selfsustainable state of Bosnia-Herzegovina.

\section{High Representative and State-Building Process in Bosnia- Herzegovina}

Lerner's (1989) view of political action indicated in sentence: "what is hard for them, is to govern themselves" (p. 88) indicates the position of local political actors in Bosnia-Herzegovina. The current political crisis in Bosnia-Herzegovina is partly due to excessive dependency on the international community and the High Representative by the local political actors. Therefore, the international community and the OHR are often considered as being responsible for resolving all political and socio-economic predicaments of Bosnia-Herzegovina. Furthermore, some perceptions have the extreme view that the OHR should act for the benefit of peoples in almost all affairs of the state.

The beginning of OHR's mission in Bosnia-Herzegovina is ambivalent. The ambiguity of its mission and disunity of the international community highly affected the role and position of OHR in BosniaHerzegovina. Misunderstanding of Annex 10 and the overwhelmingly complicated political situation led to several meetings of the PIC Steering Board with an aim to clarify the position and the role of OHR.

The early phase of OHR was characterized by self-search and self-defining (Bildt, 1998, p. 352. The significant inclusion of the OHR began with the general elections in 1996 (International Crisis Group (ICG), 1996). Bosnia-Herzegovina for the first time since 1992 got a central government, which consisted of representatives of all people and citizens, from the entire territory of Bosnia-Herzegovina. Warring parties had to sit together in the offices of central government. These parties grabbed the opportunity to launch the process of ethnicisation instead of democratization, which had legalized their war gains. This is well described by David Chandler (2000) who holds that:

Democratisation strategy in Bosnia has relied heavily on the institutionalisation of ethnic division through the use of the 'ethnic key', the allocation of seats in advance on the basis of ethnicity... While the ethnicisation of politics has been welcomed, and multi-ethnic administration 
formed at all levels, the politicisation of ethnicity, the success of political parties which appeal to on ethnic group, has been roundly condemned as a central barrier to democratisation and the Dayton process. (p. 111)

In such complex governance framework exemplified by the division and disagreement on the ethnic grounds, an active participation of the OHR was both desirable and necessary. However, OHR's inclusion in the process of the establishment of a functional state eventually led to "the Bell Jar." Therefore, Bosnia-Herzegovina has been perceived as "a protectorate", semi-protectorate", "colony" and "controlled democracy," which was in contradiction with the conception of Western democracy. In this regard, Bojkov (2003) argues that: the political system of Bosnia and Herzegovina would elicit the following definition of controlled democracy a compact of external democracy promotion whose nondemocratic elements, often inconsistent with each other, are directly inserted in the target country and enjoy farreaching powers of control, constituting a direct, nondefiable, and certainly nonjustifiable, influence over its political development (pp. 42-3).

As a result of the "controlled democracy," with excessive involvement of the international community and the OHR, local political actors could not often reach agreement on important political issues and instead, the High Representative had to make inevitable decisions. Similarly, since Bonn conference and until 2000 numerous decisions (OHR, www.ohr.int/decision/archive.asp) for the sake of building the functional democratic state have been made. The most significant laws have been imposed by the OHR because of disagreement and the inability of local political actors to adopt them. Adoption of these laws was the earliest intention of HR to create a more functional state. Besides, these laws represented an important step towards political reconciliation as Bojkov argued: "the HR has had to impose laws important for creating conditions for reconciliation and for the functioning of a multiethnic state administration" (Bojkov, 2003, p. 58). High Representatives have also practiced the 'removal' mechanism for political actors that violated the 
DPA (Ebner, 2004) The HR 'removed' around 60 officials and political authorities from political scene (OHR, 1998-2000. Retrieved September 13, 2011, www.ohr.int/decision/archive.asp)

In the economic sphere the crucial and critical decision of PIC was the establishment of a state treasury. This became the base for further common state economic space in taxation, standard, banking system, a unified currency and competition policy (PIC, 2000b). Such economic unification also led to greater re-integration of Bosnia-Herzegovina at state, entity and cantonal levels. For instance, the introduction of KM as state currency was one of the most significant unification factor:

The K-mark has been well received, one of the few unifying institutions in Bosnia. A currency board prevented the entities and politicians from manipulating the money supply, which would have generated inflation, endangering Bosnia's economic recovery (Dobbins et al., 2008, p. 150).

In 2003, High Representative Paddy Ashdown paved the way for the establishment of_Army Force, State Intelligence Agency (SIPA) and indirect taxation, all as the part of Bjelašnica Declaration (Cousen \& Harland, 2006, p. 116-119; Tuathail, 2006). The OHR period from 2000 to 2005 could be assessed as the most important and most productive. During this period High Representatives successively, imposed 757 decisions, removed 119 officials and enforced 286 laws or amendments to the laws (Woekl, 2011, p. 17). Therefore, all these changes which were imposed or made under OHR supervision were tolerated, with the existence of different opinions about its impact in the future, at the international scene. It is important to emphasize the fact that all these changes initiated by OHR, as well as reforms of judiciary and prosecutorial councils, were either accepted or tolerated at the domestic level. They were accepted due to the requirement on the path to EU accession and NATO Partnership for Peace Program.

During this period, Bosnia-Herzegovina was presented as a successful mission at the international scene, especially its progress towards Euro-Atlantic integrations. However, the international community overstated the role of local political actors and 
underestimated the role of OHR, which resulted in strong calls for its termination/transformation. In this regard, Paddy Ashdown was seen as the last High Representative who exercised his full capacity. His successor, Christian Swartz Schilling, therefore exclaimed "You are aware that I may be the last High Representative. This function and this office will disappear in the near future."

However, in spite of the above significant developments, as Lerner argued in his work, it was hard for local political actors to govern Bosnia-Herzegovina without international help. Yet, the international community, being politically divided itself, had difficulty to position itself accordingly. Therefore, the international community has been often criticized:

Rather than state-building, it would appear that 'informal trusteeship' or 'shared sovereignty' under the framework established by the Dayton agreement, have done little to either build the capacity of the Bosnia state or to legitimate it in the eyes of the population (Chandler, 2006, p. 33).

The above discussion indicates that the High Representative contributed to the effective and focused institutions-building in BosniaHerzegovina. OHR played a significant and crucial role in the process of the establishment of the state institutions. The warring parties and presence of hostilities would result in delayed building of state institutions if the OHR did not intervene in paving the way (OHR, 1997, paragraph 19).

\section{"The Constituent People" and the "April Package"}

The earliest local political initiative was introduced by Alija Izetbegović - Chairman of Bosnia-Herzegovina Presidency. He made an appeal on the issue of "constituent people" (Bojkov, 2003, p. 41-67) to the Constitutional Court of Bosnia-Herzegovina. ${ }^{1}$ Apparently, the constitutions of entities on this issue collided with the constitution. The Constitutional Court made the decision requesting revisions of entities constitutions. However, this decision represented only one more "decision on paper" whereby entities acted indifferently upon this 
decision. Considering the situation the OHR had to act to pave the way for the implementation of court's decision by forcing the local political actors on the issue of the "constituent people." This agreement, made with high OHR pressure became known as the "Sarajevo Agreement." Its significance was also highlighted by PIC Steering Board as "a decisive step forward in terms of Bosnia and Herzegovina's democratic development and commitment to the rule of law" (PIC, 2002, www.ohr.int/pic). Sarajevo Agreement set "symmetrical" limits to the entities in term of power-balance and, as well as, the protection of vital national interests of constituent peoples in both entities (Mujkić, Seizović $\&$ Abazović, 2008, p. 24). Public opinion and the opinion of the judges of the Constitution Court of Bosnia-Herzegovina differed. For instance, Snežana Savić one of the Constitutional Court judges said:

If the decision of the Constitutional Court of $\mathrm{BiH}$ on the constituent peoples in Republika Srpska and in the Federation is implemented, then the survival of the structures defined in the $\mathrm{BiH}$ constitution will be called into question. This decision opens the possibility of changing the constitution of $\mathrm{BiH}$, which is very dangerous, because it calls into question the Dayton Agreement. (as cited in ICG, 2002, p. 7).

The politicians from the entity Serb Republic held that the decision of the Constitutional Court of Bosnia-Herzegovina on "constituent peoples" was devastating for DPA and entity Serb Republic. Vitomir Popović argued "this agreement leads to the disappearance of the RS and it will, insofar as it is accepted, remain but dead words on paper" (as cited in ICG, 2002, p. 8). The public opinion created by politicians and the media in entity RS saw this as loosing the advantages gained during the war and in Dayton.

The Croats also assessed the Sarajevo Agreement, even though it was acceptable for Government of Republic of Croatia. They viewed it negatively as "treason of Croatian people." "Vrbošić's Mostar intervention and HDZ's appeal to sign the Agreement, was assessed as final punch of Zagreb by "the knife in back" to the Croats in BosniaHerzegovina, and finally the "hand-washing" from the attempt of seeking the equality of Croats with other constituent people in Bosnia- 
Herzegovina" (http://arhiv.slobodnadalmacija.hr/20020408/temedana02.asp). The Bosnian Croats advocated that Bosniaks would manipulate with the category of "others" in $\mathrm{FBiH}$ in order to achieve the majorization through 'phony' others (ICG, 2002, p. 14).

Such change in a course of international community politics, now mainly led by European Union, significantly contributed towards current crisis in Bosnia-Herzegovina. The efforts made by the international community in the past now by one serious constitutional change, which is basically the root of the Bosnia-Herzegovinian problems, failed. By the collapse of the negotiations on the amendments to the Constitution of Bosnia-Herzegovina, so called "April Package," nationalism reemerged as in early 1990s (Fethagić \& Mustajbegović, p. 21-22). Furthermore, "since the unsuccessful voting on the 'April package' of the constitutional reforms in 2006 , the only topics which have been subject to political negotiations are those related to the territorial reorganization of the country" (VPIBIH, 2009, p. 7). In all this whirlpool of nationalistic ideas the international community looked as it "lost strings" and exhausted all the ideas related to the solution of the issues in BosniaHerzegovina. That passivity of the international community will highly effect the position, mandate and authority of OHR in forthcoming years. Cluelessness of the politics of international community was largely manifested through the creation and adoption of the "exit strategy" on closure of the OHR and transformation of its authority in the Office of the Special Representative of European Union (EUSR) to BosniaHerzegovina.

\section{"Exit Strategy" of the International Community}

The international community issued the "package" of objectives needed to be fulfilled for the closure of OHR by the beginning of 2008 . The objectives needed to be delivered by the local political actors of Bosnia-Herzegovina included:

- Acceptable and Sustainable Resolution of the Issue of Apportionment of Property between State and other levels of government; 
- Acceptable and Sustainable Resolution of Defence Property;

- Completion of the Brčko Final Award;

- Fiscal Sustainability (promoted through an Agreement on a Permanent ITA Co-efficient methodology and establishment of a National Fiscal Council);

- Entrenchment of the Rule of Law (demonstrated through Adoption of National War Crimes Strategy, passage of Law on Aliens and Asylum, and adoption of National Justice Sector Reform Strategy) (PIC, 2008)

Although PIC has already decided on a closure of OHR, current political reality in Bosnia-Herzegovina is entirely different. Besides, the OHR is a part of a DPA and PIC was established later as a body responsible for peace implementation led by High Representative. Therefore, OHR as an institution is older and higher ranked than PIC, and this is supported by the fact that High Representative submits reports directly to the UN Security Council (Chandler, 1998, p. 11) This situation results in the question does the PIC Steering Board have the mandate to change the DPA without the consent of the signatories of the Agreement, among which are Bosnia-Herzegovina, Serbia and Croatia?

Apparent contradiction often emphasized is 5+2 Strategy, which is actually considered as sufficient for the closure of OHR. However, the resolutions of UN Security Council, as a top world organization, are, gently said, superior in every aspect to all bodies which are under the auspices of this organization. Therefore, the PIC Conclusions are subordinated to the Security Council. In this regard, the Resolution 1031 on Peace Implementation in Bosnia-Herzegovina is superior to PIC Conclusions. Therefore, the emphasis of the Resolution on full Peace Implementation is superior to the PIC decision on " $5+2$ Strategy" which narrows the framework of the Resolution. To allay any doubts in this regards, it is important to emphasize that the Bonn Conference and its conclusions adapted in 1997 in the regard of increment of the capacity, 
authority and mandate of OHR were also confirmed by UN Security Council.

Based on the Resolution 1031 the condition for the closure of the OHR is the fulfillment of its Mission. However, by considering the Mission and apparent list of the tasks entrusted to the OHR in Annex 10 of DPA, ${ }^{2}$ it could be deduced that OHR failed in its mission DPA has been only partially implemented.

By considering the complexity of the political situation and power struggle among both international and local political actors, early exit strategy would have been disastrous for the future of BosniaHerzegovina. It is obvious that the international community is currently involved in many conflict areas around the world but it's ultimately responsibility is to shoulder peace, security and state-building processes in Bosnia-Herzegovina. However, former strategies of the international community have been proven partially successful and perhaps current political predicaments of Bosnia-Herzegovina should be considered by developing new much more functional strategies.

\section{Discussion and Recommendations}

During the pre-war period in Bosnia-Herzegovina the fear has been used as a key factor in the process of segregating and ghettoizing the people. As a result of such politics even the constituent peoples in Bosnia-Herzegovina are ghettoized within its territory and ethno-politics. Therefore, Bosnia-Herzegovina is currently facing its gravest political crisis. I would like to use strong emphasis to illustrate the situation by stating that the war in Bosnia-Herzegovina has only been transformed from military to political war, which currently reached its climax.

The causes of political crisis in Bosnia-Herzegovina are due to inability of both international and local political actors. The responsibility of international community lies in a fact that their changeable objectives have never ever been brought to the state of completion and implementation. In addition, such an excessive involvement of the international community created a fake sense among local political actors who held themselves of being not accountable for the current political crisis and overall the situation. Their dependency politics resulted in 
being accountable neither to the international community nor to its own citizens and electorate. Furthermore, interventionism of the international community and emphasis on a dialogue-culture and consultations among local political actors has never given solid results. Then, advocacy for the OHR continuing or leaving role in Bosnia-Herzegovina had opened many unanswered questions.

The international community facilitated the process of institutionbuilding which has been a vital for making an image of BosniaHerzegovina as being a stable and self-sustainable European state. However, the international community must find ways and means of engaging the local political actors to transform DPA Bosnia-Herzegovina to Bosnia-Herzegovina as EU member state. Therefore, the top-down system of state-building should rather be reverted to bottom-up step by step strategy.

\section{References}

Books and articles:

Asim Mujkić, Zarije Seizović and Dino Abazović, The role of human and minority rights in the process of reconstruction and reconciliation for state and nation-building: Bosnia and Herzegovina, EURAC Research, 2008, 24.

Berit Bliesman de Guevara, States of conflict: a case study on peacebuilding in Bosnia and Herzegovina, London: IPPR, 2009.

Carl Bildt, Peace journey: The struggle for peace in Bosnia, London: Weidenfeld and Nicolson, 1998.

Christian J. Ebner, “The Bonn Powers -still necessary?” in (ed.) Predrag Jurekovi and Frederic Labarre, From peace making to self sustaining peace -International presence in South East Europe at a crossroads? Vienna: National Defence Academy, 2004.

David Chandler, "Democratization in Bosnia: The limits of civil society building strategies," Democratization, (Vol.5, No.4, December 1998).

David Chandler, Bosnia: Faking democracy, $2^{\text {nd }}$ ed., London: Pluto Press, 2000. 
David Chandler, "State-building in Bosnia: the limits of "informal trusteeship" International Journal of Peace Studies, (Vol. 11, No. 1, Spring/Summer, 2006).

Derek Chollet, The road to the Dayton Accords, New York: Palgrave, 2005.

Edin Šarčević, Dejtonski ustav: karakteristike i problemi, Ljubljana: IFIMES, 2009.

Elisabet Cousen and David Harland, "Post-Dayton Bosnia and Herzegovina", in (ed.) William J. Durch, Twenty-first-century peace operations, Washington: United States Institute of Peace, 2006.

Emir Hadžikadunić, Od Dejtona do Brisela, Sarajevo: ACIPS, 2005.

Evelyn Farkas, Fractured states and US foreign policy: Iraq, Ethiopia and Bosnia in the 1990s, New York: Plagrave Macmilan, 2003.

Gearoid O Tuathail, "Geopolitical discourses: Paddy Ashdown and the tenth anniversary of the Dayton Peace Accords", Geopolitics, (11: 141-158, 2006), Taylor and Francis Group.

Haris Abaspahić and Reuf Bajrović, Perspektive politike Evropske unije prema Bosni i Hercegovini, Centar za politike i upravljnje Heinrich Boll Stiftung BiH, Sarajevo, 2010.

Haris Hromić, "Pregled vanjske politike SAD-a", Foreign Policy review, Sarajevo: Fondacija Friedrich Ebert, 2006.

James Dobbins, Seth G. Jones, Keith Crane, Christopher S. Chivvis, Andrew Radin, F. Stephen Larrabee, Nora Bensahel, Brooke K. Stearns, Benjamin W. Goldsmith, Europe's role in NationBuilding: From the Balkans to the Congo, Santa Monica: Rand Corporation, 2008.

Jens Woekl, "Bosnia-Herzegovina: Trying to build a federal state on paradoxes" in Michael Burgess, Alan Tarr (eds.), Constitutional dynamics in federal systems: Sub-national perspectives, McGillQueen's University Press, 2011.

Karl Bildt, Misija mir, Sarajevo: ZID.

Kasim Trnka, Ustavno pravo, Sarajevo, 2000.

Marcus Cox, State-building and post-conflict reconstruction: Lessons from Bosnia, CASIN, Geneva, 2001. 
Max Lerner, It is later than you think: The need for militant democracy, New Jersey: Transaction Publisher, 1989.

Omer Ibrahimagić, Supremacija Bosne i Hercegovine nad entitetima, Sarajevo: Vijeće Kongresa Bošnjačkih intelektualaca, 1999.

Reberto Belloni, "Civil society and peacebuilding in Bosnia and Herzegovina", Journal of Peace Research, 2001: Vol. 38, No. 2.

Richard Holbrooke, To end a war, Random House inc., 1998.

Sead S. Fetahagić and Saida Mustajbegović, Evropski pokret za evropski ustav, Sarajevo: ACIPS.

Sead Turcalo, "Međunarodna zajednica i izgradnja neuspješne države", Status, No. 13 Mostar: Dijalog, 2008.

Sylvie Ramel, "Od neokolonijalne Međunarodne zajednice do posthegemone Europe", Status, No. 13, Mostar: Dijalog, 2008.

Victor D. Bojkov, "Democracy in Bosnia and Herzegovina: Post-1995 political system and its functioning", Southeast European Politics, No. 1, (2003).

Reports and Analysis

OHR, 2011. 40 $0^{\text {th }}$ Report of the High Representative for implementation of the Peace Agreement on Bosnia and Herzegovina to the Secretary-General of the United Nations, available at: http://www.ohr.int/other-doc/hrreports/default.asp?content id =46579; (01.12.2011);

OHR, Recalibrating the activities of the International Community - The challenges of partnership, (Brussels, 13 September 2001) available at: www.ohr.int

OHR, $5^{\text {th }}$ Report of the High Representative for implementation of Bosnian Peace Agreement to the Secretary-General of the United Nations, 1997, paragraph 19.

OHR, $6^{\text {th }}$ Report of the High Representative for implementation of Bosnian Peace Agreement to the Secretary-General of the United Nations, 1997, paragraph 18.

OHR, Bjalašnica Declaration, 2003, available at: http://www.ohr.int/archive/bjelasnicadeclaration/default.asp?content_id=29804 
OHR, Plans and funding requirements for 1999, Sarajevo: OHR, 1998, available at: www.ohr.int/print/?content_id=4677

OHR, Presentation to PIC Steering Board Political Directors, Recalibrating the activities of the International Community - The challenges of partnership, Brussels, 13 September 2001.

OHR, Removals and suspensions from office, 1998-2000, available at: www.ohr.int/decision/archive.asp, (13.09.2011).

PIC, 2011. Statement by the Steering Board of the Peace Implementation Council, available at:

http://www.ohr.int/pic/default.asp?content_id=46469, (03.10.2011)

PIC, Declaration, Brussels, September 2001.

PIC, "Bosnia and Herzegovina: Self-sustaining structures", PIC Conclusions, Bonn: PIC, 1997. Available at: www.ohr.int/pic

PIC, "Economy" in: Annex to the PIC Declaration: required actions, May 2000a.

PIC, Communiqué by PIC Steering Board, Sarajevo: PIC, 2001, available at: www.ohr.int/pic.

PIC, Communique of the PIC Steering Board, 27. Mart 2002. Dostupno na: $\underline{\text { www.ohr.int/pic }}$

PIC, PIC Communiqué, 27. February, 2008, available at: http://www.ohr.int/pic/default.asp?content_id=41352

PIC, PIC Declaration - Annex, Brussels: PIC, 2000b. Available at: www.ohr.int/pic

PIC, Sintra Declaration, Communiqué, Sintra: PIC, 1997, par.70. Available at: www.ohr.int/pic

VPIBIH, Uloga civilnog društva u reformi ustava u BiH, 2009. Available at:

http://www.vpi.ba/eng/content/documents/Role_Of_Civil_Society in_BiH_Constitutional_Reform.pdf

ICG, Implementing equality - The "Constituent Peoples" decision in Bosnia and Herzegovina, 2002, available at:

http://www.crisisgroup.org/ /media/Files/europe/Bosnia\%2045.pdf

ICG, Elections in Bosnia \& Herzegovina, Sarajevo: ICG, Report no. 16, 1996. Available at: 


\section{http://www.crisisgroup.org/ /media/Files/europe/balkans/bosnia- herzegovina/Bosnia\%202.pdf}

1 Article VI of the Dayton constitution mandated the establishment of a $\mathrm{BiH}$ Constitutional Court. It has nine justices: four selected by the Federation House of Representatives, two by the RS National Assembly and three by the European Court of Human Rights "after consultation with the $[\mathrm{BiH}]$ presidency". In practice, this has meant that the court is composed of two Bosniaks, two Croats, two Serbs and three foreigners. Part of the court's remit is to determine "[w]hether any provision of an Entity's constitution or law is consistent with this Constitution". In addition, Article XII of the state constitution required that within "three months from the entry into force of this Constitution, the Entities shall amend their respective constitutions to ensure their conformity with this Constitution..." The General Framework Agreement for Peace in Bosnia and Herzegovina, Annex 4, Article VI,1(a), Article VI,3(a) and Article XII,1.

${ }^{2}$ Monitor the implementation of the peace settlement; Maintain close contact with the parties to the Agreement, to promote their full compliance with all civilian aspects of the Agreement; Co-ordinate the activities of the civilian organisations and agencies in Bosnia and Herzegovina to ensure the efficient implementation of the civilian aspects of the peace settlement. The High Representative shall respect their autonomy within their spheres of operation while as necessary giving general guidance to them about the impact of their activities on the implementation of the peace settlement; Facilitate, as the High Representative judges necessary, the resolution of any difficulties arising in connection with civilian implementation; Participate in meetings of donor organisations; Report periodically on progress to the United Nations, European Union, United States, Russian Federation and other interested governments, parties and organisations; (www.ohr.int /Mandate) 